\title{
The Use of Task-Based Reading Method in Improving Student Reading Fluency in Learning Teaching Processes
}

\author{
M Yunus \\ Universitas Muslim Indonesia, Makassar, Indonesia \\ muhammad.yunus@umi.ac.id
}

\begin{abstract}
In the present study, the use of task-based reading for English language students in improving student reading fluency was examined. This research aimed to explore the effectiveness of task-based reading for English language students in improving reading fluency in learning teaching processes. The students in the treatment group were taught using task-based reading once a week to improve student reading fluency. The students in the controlled group used the conventional reading technique to improve one. The results indicated that the use of task-based reading was effective to improve the student reading fluency shown by the test results of pair samples t-test of the p-value below 0.05 . Thus, the taskbased reading is recommended to be used as the instructional materials on Reading Comprehension for the students of English Education Fakultas Sastra Universitas Muslim Indonesia.
\end{abstract}

Keywords: Effectiveness, Task-Based Reading, English Education

\section{INTRODUCTION}

In our life, reading is pivotal because it is the main key to explore the world. The first verse revealed by Allah, the God of the universe to His Last Messenger, Prophet Muhammad, is the command to read as the word of Allah in the Surat al-iqra verse (1) iqra means "read in (the) name (of) your Lord the One Who created." This means reading is something that will bring benefits to humanity as the servants of God Almighty.

Our lives are never far from reading which is deemed the most important aspect of daily activities. The information flow requires active reading, meaning interpretation to understand and evaluate. The active reading is the combination of reading with critical thinking and learning and is a fundamental part of education and knowledge work. It involves not just reading per se, but also underlining, highlighting and scribbling, either on the text or in a separate notebook[1]. Even in reading materials, such as magazines, newspapers, scientific books, articles, and other printed materials demand active reading skills to obtain the information in them. Especially in the world of education, reading proficiency is fundamental because all learning and teaching processes are based on literacy. Through active reading activities, we can explore the breadth of the world science which is spreading around the world and from various fields of knowledge. Reading for comprehension involves the relationship between meaning and word symbol, the choice of appropriate meaning based on the context, the organization of sense, and the ability to give arguments and catch ideas[2]. It may include a set of learning goals for 1) the ability to read a wide range of texts in English. This is the long-range goal most lecturers seek to develop through independent readers outside English Foreign Language (EFL)/English Second 
Language (ESL) classroom, 2) building a knowledge of language which will facilitate reading ability, 3) building schematic knowledge, 4) the ability to adapt the reading style according to reading purpose (i.e. skimming, scanning), 5) developing an awareness of the structure of written texts in English, 6) taking a critical stance to the contents of the texts [3].

The research observing the lecturers who teach Reading Comprehension in Indonesian EFL university students showed that most first semester students have difficulties understanding the coursebooks used by the lecturers (Interview of the students of the Reading Comprehension I, 2017). As evidence at Department of English Education context, the research about the difficulties faced by the students in reading comprehension states that the lecturers use a traditional approach where the essential exercises after completing the readings are to answer comprehension questions. The lecturers ask students to read the textbook, then to translate it into Indonesian, and finally to answer questions to demonstrate understanding. This approach is called the Grammar Translation Method, which is the most traditional approach to teaching language.

Based on the problems mentioned above, it requires a method of teaching reading which is based on a task-based reading to improve the student reading fluency. This instructional reading material focuses on the tasks as the core unit of planning and instruction in language teaching which reflect the cognitive learning process related to the situation outside of the classroom[4]. Immersing students in the tasks provide a better context for the activation teaching-learning process, and hence ultimately offers better chances for language learning to take place [5]. Further, teaching through tasks creates favorable learning conditions for students who study English for specific purposes[6]. In the analysis, task-based instruction provides for meaningful language use and promotes autonomous learning. Introducing task-based instruction as a practical methodology can completely transform EFL coursebooks. Again by creating such student-centered and interactive learning materials, lecturers can achieve communicative goals and help their students to become more motivated[7]. Thus the research aims to determine the use of task-based reading to improve the student reading fluency.

\section{METHODS}

The subjects were 20 fresh students, drawn from class $\mathrm{C} 1$ at the Department of English Education Fakultas Sastra UMI. The students were placed in the treatment class on the taskbased reading materials. The treatments employed were a task-based reading material and a conventional reading material.

Task-based reading. During the treatment, the students completed all of the reading assignment based on the task-based interpretation. In these assignments, three principle task types were used: information gap, reasoning gap, and the opinion gap. a) Information gap activity involves a transfer of given information from one person to another or from one form to another, or from one place to another. b) Reasoning gap activity involves deriving some new information from given information through processes of inference, deduction, practical reasoning, or perception of relationship or pattern. c) Opinion gap activity involves identifying and articulating a personal preference, feeling, or attitude in response to a given situation. One example is story completion; another is taking part in the discussion of a social issue. The activity may involve using factual information and formulating an argument to justify one's opinion, but there is no objective procedure for demonstrating outcomes as right or wrong, and no reasons to expect the same result from different individuals or on different occasions.

Conventional reading. In the treatment, the students completed all of the reading assignment based on the passage structure. In these assignments, two principle task types were used micro 
and macro. The microanalysis involves keeping track of transitions, which signal the flow of the passage. Transition or guide words, including such words as but and however, have been called the traffic lights of language. These words serve one of four primary purposes: to show continuation, illustration, contrast, or conclusion. The macro analysis involves not only noting the number of paragraphs and their function but more importantly, the number of viewpoints and their relationship [8].

\section{RESULTS and DISCUSSION}

The pre and posttest means for the task-based reading materials are contained in Table 1. The mean of the posttest (86.5500) was significantly greater than the mean of pretest $(51.5000)$. The differences for the treatment were significant, $\mathrm{F}(0.00)=0.00>0.05$. However, there was a correlation as significant as -.107 between the pretest and the posttest, because of sig 0.653 .

The results from this study warrant further discussion. There was a significant achievement by using task-based reading materials treatment. This was indicated by the test results of the following:

Table 1. Paired Samples Statistics

\begin{tabular}{llllll}
\hline & & & \multicolumn{2}{c}{ Std. } & Error \\
& & Mean & N & \multicolumn{2}{c}{ Std. DeviationMean } \\
\hline \multirow{2}{*}{ Pair 1 } & Pre Test & 51.5000 & 20 & 15.73631 & 3.51875 \\
\cline { 2 - 6 } & Post Test & 86.5500 & 20 & 8.00312 & 1.78955 \\
\hline
\end{tabular}

Table 2. Paired Samples Correlations

\begin{tabular}{lllll}
\hline & & N & Correlation & Sig. \\
\hline Pair 1 & Pre Test \& Post Test & 20 & -.107 & .653 \\
\hline
\end{tabular}

Paired Sample T-Test was used to determine the effect before and after the treatment. The following is the SPSS output data for the experimental group using paired sample T-test:

Table 3. Paired Samples Test

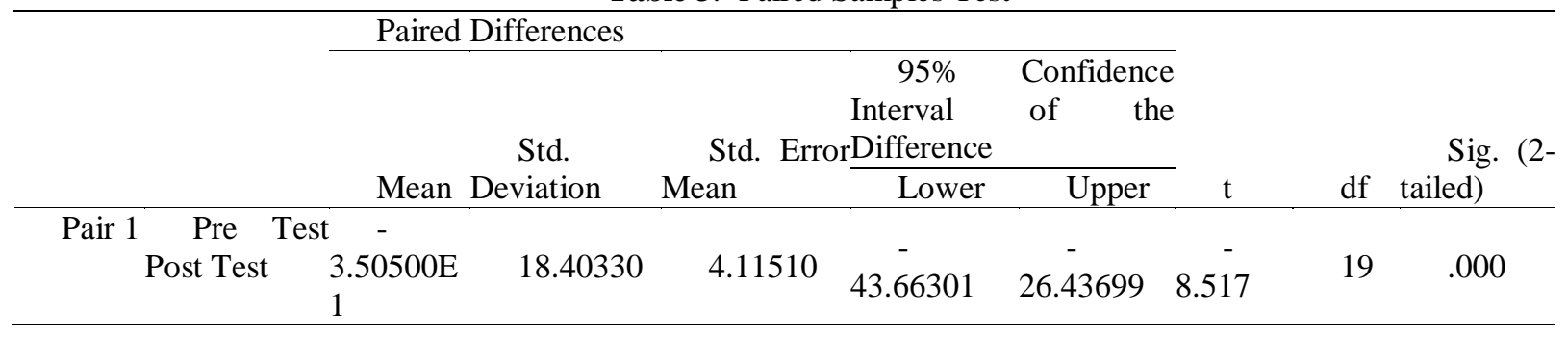

If the significance value is $\mathrm{p}<0.05$, it means that there are differences before and after the treatment. The paired samples T-test table above showed that the significance value of 0.00 , which is smaller than 0.05 . It means that there is a change in reading fluency in the participants before and after the treatment in the Std section. Error Mean showed a value of 4.11510 (positive). That means that there is a tendency to improve reading fluency from before to after 
treating (studying based on task-based reading materials). In conclusion, in the experimental group, there was the effect of studying based on task-based reading materials on reading fluency.

The following is the SPSS output data for the control group using the Paired Sample T-Test: Table 4. Paired Samples Test

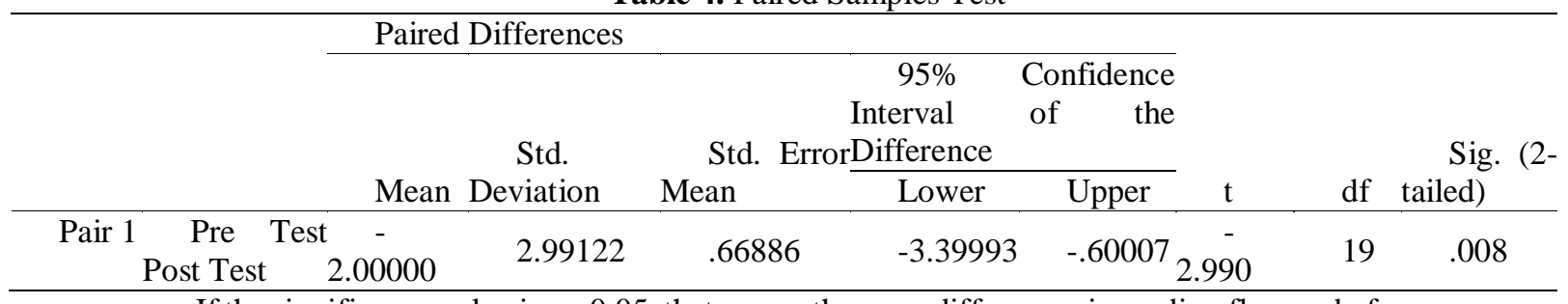

If the significance value is $\mathrm{p}<0.05$, that means there are differences in reading fluency before and after studying conventional reading technique. The paired samples T-Test table above showed that the significance value is 0.008 , which is bigger than 0.05 meaning that there is no change in reading fluency in the control group participants. In conclusion, in the control group, there was no effect of studying conventional reading technique on reading fluency.

\section{CONCLUSION}

In the experimental group, there was effectiveness of studying based on task-based reading on student reading fluency while in the control group there was no effect of studying conventional reading technique on reading fluency. This was indicated by the test results of the pair samples t-test of the p-value of 0.00 , which is smaller than 0.05 . Therefore, the use of taskbased reading is fruitful to be used as the instructional materials on Reading Comprehension in improving student reading fluency in Faculty of Letters UMI.

\section{REFERENCES}

[1] M. N. Price, B. N. Schilit, and G. Golovchinsky, "XLibris," in CHI 98 conference summary on Human factors in computing systems - CHI '98, 1998, pp. 22-23.

[2] A. Hamra and E. Syatriana, "A Model of Reading Teaching for University EFL Students: Need Analysis and Model Design,” English Lang. Teach., vol. 5, no. 10, pp. 1-11, Aug. 2012.

[3] F. B. Davis, "Fundamental factors of comprehension in reading," Psychometrika, vol. 9, no. 3, pp. 185-197, Sep. 1944.

[4] Gunning and T. G, Reading Comprehension Boosters. San Francisco: Jossey-Bass, 2010.

[5] J. C. Richards, "The language teaching matrix," Journal of Southeast Asian Education, vol. 2. pp. 373-412, 1990.

[6] M. R. Cuesta Cuesta, "A task-based approach to language teaching: the case for taksbased grammar activities," Rev. Alicant. Estud. Ingleses, vol. 8, no. 8, pp. 91-100, 1995.

[7] D. Nunan, Task-Based Language Teaching. New York: Cambridge University Press, 2004.

[8] Royal B, GMAT Reading Comprehension. Alberta: Maven Publishing, 2011. 